\title{
PENYALURAN BANTUAN LANGSUNG TUNAI DANA DESA NANGA AMBALAU KECAMATAN AMBALAU
}

\author{
MIKAEL MAHIN \\ Fakultas Ilmu Sosial Dan Ilmu Politik Universitas Kapuas Sintang \\ Jalan J.C Oevang Oeray Nomor 92 Sintang Kalimantan Barat \\ Email: mahinmikael@gmail.com
}

\begin{abstract}
ABSTRAK: Penyaluran bantuan langsung tunai dana Desa Nanga Ambalau Kecamatan Ambalau Kabupaten Sintang telah dilaksanakan. Pada saat sosialisasi program bantuan langsung tunai disampaikan kepada masyarakat bagaimana mekanisme dan Alur Pendataan Calon Penerima BLT-Dana Desa. Mekanisme pendataan keluarga miskin dan rentan calon penerima BLT-Dana Desa serta penetapan hasil pendataannya: Proses Pendataan, Perangkat Desa menyiapkan data desa yang mencakup profil penduduk desa berdasarkan usia, kesejahteraan, pendidikan, kesehatan, dan disabilitas. Kepala Desa membentuk dan memberikan surat tugas kepada Relawan Desa dan/atau Gugus Tugas Covid-19 untuk melakukan pendataan keluarga miskin calon penerima BLT-Dana Desa.Data yang diterima masyarakat Desa Nanga Ambalau KecamatanAmbalauKabupaten Sintang bantuan langsung tunai Dana Desa Covid 19 adalah sebesarRp. 600.000/Bulan masyarakat yang menerima sebanyak 58 Kepala Keluarga untuk bulan April, Mei, Juni Tahun 2020. Sedangkan masyarakat yang menerima untuk bulan Juli, Agustus, September Tahun 2020 sebesar Rp. 300.000/Bulan sebanyak 58 Kepala (KK).Sumber daya manusia dalam menunjang pelaksanaan penyaluran bantuan langsung tunai Desa Nanga Ambalau melibatkan semua pihak seperti pemerintahan Desa dan perangkatnya. Dalam struktur pembentukan relawan gugus tugas Covid-19, Kepala Desa menjadi Ketua dan wakilnya adalah Ketua BPD serta anggotanya terdiri dari seluruh perangkat desa, anggota BPD,Linmas, PKK, Lembaga Desa, sedangkan Babinsa bertindak selaku mitra.
\end{abstract}

Kata Kunci: Penyaluran,Bantuan Langsung Tunai, Dana Desa.

\section{Pendahuluan}

Seiring perkembangan penanganan covid19 serta dalam upaya mempercepat penyaluran Dana Desa dalam mendukung pelaksanaan Bantuan Langsung Tunai Desa, persyaratan dan tahapan penyaluran Dana Desa mengalami penyesuaian. Adapun penyesuaian dimaksud adalah relaksasi kebijakan penyaluran Dana Desa untuk mempercepat realisasi pelaksanaan penggunaan Dana Desa untuk Bantuan Langsung Tunai. Dalam kondisi ini Pemerintah Desa perlu segera menyikapi dengan melakukan perubahan dokumen perencanaan dan penganggaran yang akan difokuskan untuk penanggulangan covid-19 di desa.

Terbitnya Peraturan Pemerintah pengganti undang-undang Republik Indonesia Nomor 1 Tahun 2020 tentang Kebijakan Keuangan Negara dan Stabilitas Sistem Keuangan Untuk Penanganan Pandemi Corona 2019 (Covtd- Le) dan/atau dalam rangka menghadapi ancaman yang membahayakan perekonomian nasional dan/atau stabilitas sistem keuanganmemberikan instrumen baru untuk meminimalkan dampak pandemi Covid-19 terhadap perekonomian desa. Pada Pasal 2 Ayat (1) huruf (i) peraturan tersebut disebutkan bahwa perlu dilakukan pengutamaan penggunaan alokasi anggaran untuk kegiatan tertentu (refocusing), penyesuaian alokasi, dan/atau pemotongan/ penundaan penyaluran anggaran transfer ke daerah dan dana desa, dengan kriteria tertentu. Selanjutnya dalam penjelasan Peraturan Pemerintah tersebut disebutkan bahwa yang dimaksud dengan pengutamaan penggunaan dana desa adalah dana desa dapat digunakan antara lain untuk bantuan langsung tunai bagi penduduk miskin di desa dan kegiatan penanganan pandemi Covid-19. Dengan adanya pasal penjelasannya tersebut, perlu dilakukan kajian bagaimana kebijakan tersebut dapat diterapkan dengan cepat.

Implikasi pandemi Corona Virus Disease 2019 (COVID-19) telah berdampak antara lain terhadap perlambatan pertumbuhan ekonomi nasional, penurunan penerimaan negara, dan peningkatan belanja negara dan pembiayaan, sehingga diperlukan berbagai upaya Pemerintah untuk melakukan penyelamatan kesehatan dan perekonomian nasional, dengan fokus pada belanja untuk kesehatan, jaring pengaman sosial (social safety net), serta pemulihan perekonomian termasuk untuk dunia usaha dan masyarakat yang terdampak; 
Memperhatikan ketentuan Peraturan Menteri Dalam Negeri Nomor 20 Tahun 2018 tentang Pengelolaan Keuangan Desa pada pasal 40 ayat (2) menyatakan bahwa: "Perubahan APB Desa dapat dilakukan 1 (satu) kali dalam 1 (satu) tahun anggaran, kecuali dalam keadaan luar biasa dan ayat (3) bahwa kriteria keadaan luar biasa sebagaimana dimaksud pada ayat (2) diatur dalam Perbup/Perwali mengenai Pengelolaan Keuangan Desa (rujukan Perbup Pengelolaan Keuangan Desa Kabupaten/Kota).

Berdasarkan hal tersebut pemerintah Kabupaten melalui Kecamatan, memfasilitasi pemerintah desa agar segera melakukan perubahan dan/atau membelanjakan Anggaran Pendapatan dan Belanja Desa (APB Desa) untuk pelaksanaan kegiatan dalam rangka penanggulangan COVID19. Pelaksanaan kegiatan dimaksud dianggarkan pada Bidang Penanggulangan Bencana, Keadaan Darurat, dan mendesak Desa melalui jenis belanja tak terduga.

Penyaluran bantuan langsung tunai di Desa Nanga Ambalau KecamatanAmbalau Kabupaten Sintangselain mengedepankan Padat Karya Tunai di Desa dalam penggunaan Dana Desa, dan sebagai upaya menguatkan daya beli masyarakat, pemerintah menegaskan dalam Peraturan Pemerintah Pengganti Undang-Undang Nomor 1 Tahun 2020 yang antara lain Dana Desa dapat digunakan untuk Bantuan Langsung Tunai kepada keluarga miskin di desa dan kegiatan penanganan pandemi COVID-19.

Pada prinsipnyabantuan langsung tunai di Desa Nanga Ambalau KecamatanAmbalau, dalam keadaan luar biasa, Pemerintah Desa dapat melakukan perubahan RKP Desa dan/atau perubahan APB Desa lebih dari 1 (satu) kali dengan tetap mengikuti ketentuan/tahapan sebagaimana huruf B panduan ini. Pelaksanaan perubahan dilaksanakan dengan cara yang lebih praktis dan sederhana dengan tetap memperhatikan prinsipprinsip partisipasi, transparansi dan akuntabilitas serta tertib dan disiplin anggaran.

Bantuan langsung tunai di Desa Nanga Ambalau KecamatanAmbalaudengan memperhatikan penentuan kriteria dan mekanisme penetapan target penerima BLT, mekanisme penyaluran Dana Desa ke APB Desa, proporsi, batasan waktu pemberian, dan besaran nominal BLT yang bersumber dari Dana Desa berpedoman pada ketentuan yang diatur oleh Kementerian Keuangan dan Kementerian Desa, Pembangunan
Daerah Tertinggal dan Transmigrasi. Data yang diterima masyarakat Desa Nanga Ambalau KecamatanAmbalauKabupaten Sintang bantuan langsung tunai dana desa covid 19 sebagai berikut:Rp. 600.000/Bulan masyarakat yang menerima sebanyak 58 Kepala Keluarga untuk bulan April, Mei, Juni Tahun 2020. Masyarakat yang menerima sebanyak 58 Kepala Keluarga untuk bulan Juli, Agustus, September Tahun 2020 sebesar Rp. 300.000/Bulan.

Kecamatan Ambalau adalah sebuah kecamatan di Kabupaten Sintang, Provinsi Kalimantan Barat, Indonesia. Kecamatan dengan ibu kota di Nanga Kemangai ini merupakan kecamatan paling pedalaman dan terletak di hulu Sungai Melawi. Kecamatan ini terkenal dengan hasil hutan, beberapa HPH beroperasi di sana sampai ke Kalimantan Tengah. Sebaimana dalam data profil Desa Nanga Ambalau dengan jumlah Kepala Keluarga 177 KK yang tersebar ada dua dusun yaitu Dusun Batu bersurat berjumlah laki 81 orang perempuan 100 orang, dan Dusun Ambalau Kanan laki-laki 218 orang perempuan 226 orang. Secara administratif batas-batas wilayah Desa Nanga Ambalau Kecamatan Ambalau Kabupaten Sintang. Sebelah Utara berbatasan dengan Bukai Tukun, Sebelah Selatan berbatasan dengan Tangki, Sebelah Timur berbatasan dengan Desa Sangkai, Sebelah Barat berbatasan dengan Nanga Kemangai.

Penduduk Desa Nanga Ambalau Kecamatan Ambalau Kabupaten Sintang terus mengalami pertumbuhan setiap saat seiring dengan angka kelahiran, jumlah pendatang baru dan faktor lainnya yang kuat menambah angka jumlah penduduk.Masyarakat Desa Nanga Ambalauberjenis kelamin Laki-laki berjumlah 299 Jiwa sedangkan berjenis kelamin perempuan berjumlah 326 Jiwa. Dengan demikian bahwa masyarakat Desa Nanga Ambalau masih didominasi penduduk yang berjenis kelamin perempuan. Penduduk Desa Nanga Ambalau pada umumnya bermata pencarian sebagian besar petani dengan jumlah 438 orang, diikuti oleh lain sebanyaj 129 orang, Pegawai Negeri Sipil 7 Orang, belum bekerja 25 orang, ibu rumah tangga 10 orang, dan guru swasta 10 orang. Artinya bahwa mata pencarian penduduk rata-rata masi di dominasi oleh Petani. Hal ini didasari oleh daerah yang luas dengan kondisi masyarakat yang lebih banyak berladang atau berkebun.Data Struktur Organisasi Dan Tata Kerja Desa Nanga Ambalau,Kepala Desa: Kusnadi, Sekretaris Desa: Evodius Ental, Kaur Umum \& Perencanaan: Marta, Kepala Urusan 
Keuangan: Fransiskus Endryan, Kepala Seksi Kesejahteraan Dan Pelayanan: Yustinus Hardi Yuda, Kepala Seksi Pemerintahan: Martinus Pasang, Kepala Dusun: Adrianus Mori, Kepala Dusun: Jungan.

Peraturan Pemerintah Pengganti UndangUndang Nomor 1 Tahun 2020 (Perppu 1/2020) tentang Kebijakan Keuangan Negara dan Stabilitas Sistem Keuangan untuk Penanganan Pandemi Corona Virus Disease 2019 (Covid-19) dan/atau dalam rangka menghadapi ancaman yang membahayakan perekonomian nasional dan/atau stabilitas sistem keuangan.

Peraturan Pemerintah (Perppu)nomor 1/ 2020 ini memiliki implikasi pada kemungkinan terjadinya penurunan penerimaan desa yang bersumber dari dana desa (APBN) dan alokasi dana desa (APBD). Pada Pasal 2 Ayat (1) huruf i dinyatakan bahwa "Pemerintah berwenang melakukan pemotongan/penundaan penyaluran anggaran transfer ke daerah dan dana desa dengan kriteria tertentu." Kemudian pada Penjelasan Pasal 2 Ayat (1) hurup b disebutkan bahwa "besaran belanja wajib (mandatory) dapat disesuaikan oleh pemerintah, antara lain: anggaran untuk desa dari APBN sebesar 10\% dan di luar transfer daerah."

\section{TINJAUAN PUSTAKA}

\section{Sosialisasi Bantuan Bantuan Langsung Tunai}

Sosialisasi menurut kamus besar Bahasa Indonesia berarti upayamemasyarkatkan sesuatu sehingga menjadi dikenal, dipahami, dihayati olehmasyarakat atau pemasyarakatan. Sosialisasi dapat diartikan sebagai setiap aktivitas yang ditujukan untuk memberitahukan membujuk atau mempengaruhi masyarakat untuk tetap menggunakan produk dan jasa yang dihasilkan itu. Kemudian, Dalam kaitannya dengan kegiatan sosialisasi yang dimaksud adalah suatu prosesmemberitahukan dan memperngaruhi masayarakat untuk selalu memanfaatkan jasa-jasa yang ditawarkan.

Sosialisasi merupakan suatu proses bagaimana memperkenalkan sebuah sistem pada seseorang dan bagaimana orang tersebut menentukan tanggapan serta reaksinya. Sosialisasi ditentukan oleh lingkungan sosial, ekonomi dan kebudayaan dimana individu berada, selain itu juga ditentukan oleh interaksi pengalaman-pengalaman serta kepribadiannya.

Sosialisasi apabila dikaitkan dengan prosesnya, terdapat jenis-jenis sosialisasi. Menurut
Peter L Berger dan Luckman (2004:230) terdapat 2 jenis sosialisasi yaitu: 1) Sosialisasi primer, sosialisasi pertama yang dijalani individu semasa kecil dengan belajar menjadi anggota masyarakat (keluarga). Sosialisasi ini berlangsung pada saat kanak-kanak. 2) Sosialisasi sekunder, adalah suatu proses sosialisasi lanjutan setelah sosialisai primer yang memperkenalkan individu kedalam kelompok tertentu dalam masyarakat.

Kedua proses tersebut berlangsung dalam institusi total, yaitu tempat tinggal dan tempat kerja. Dalam keduanya institusi tersebut, terdapat sejumlah individu dalam situasi yang sama, terpisah dari masyarakat luas dan jangka waktu tertentu, bersama-sama menjalani proses kehidupan dan diatur secara formal.

Menurut Sudarsono (2017:25) syarat terjadinya sosialisasi sosialisasi merupakan system dalam kehidupan masyarakat yang sangat penting. Berdasarkan hal tersebut sosialisasi memberikan dua kontribusi fundamental bagi kehidupan masyarakat yaitu: 1) Memberikan dasar atau kondisi kepada individu bagi terciptanya partisipasi yang efektif dalam masyarakat. 2) Memungkinkanlestarinyasuatumasyarakat karena tanpa sosialisasi akan hanya ada satu generasi saja hingga kelestarian masyarakat akan sangat terganggu.

Berdasarkan uraian di atas, dapat disimpulkan bahwa melalui sosialisasi masyarakat dapat berpartisipasi untuk kepentingan hidupnyadan menciptakan generasi untuk kelestarian kehidupan selanjutnya. Selain itu, dapat faktor lain yang menunjang proses sosialisasi yaitu faktor lingkungan, dimana didalamnya interaksi sosial.

Selain faktor lingkungan terdapat factorfaktor lain yang mempengaruhi sosialisasi sebagaimana pendapat Sudarsono (2017:30), diantaranya adalah: 1) Apa yang disosialisasikan, merupakan bentuk informasi yang akan diberikan kepada masyarakat berupa nilai-nilai, norma-norma dan peran. 2) Bagaimana cara mensosialisasikan, melibatkan proses pembelajaran. 3) Siapa yang mensosialisasikan, institusi, media massa,individu dan kelompok.

Agen sosialisasi merupakan peran utama dalam keberhasilan proses sosialisasi untuk menyebarkan atau menanamkan nilai-nilai dan norma-norma yang terletak dalam materi sosialisasi. Keberhasilan terdapat ditentukan oleh 
mekanisme yang terencana dan digambarkan dalam pola proses sosialisasi yang baik. Apabila prosesproses tersebut dapat tersusun maka penyebaran informasi mengenai materi sosialisasi dapat dengan tepat disampaikan kesasaran sosialisasi.

Materi sosialisasi merupakan isi yang akan disampaikan kepada sasaran sosialisasi. Pada dasarnya, materi sosialisasi harus mengandung nilai-nilai dan norma-norma. Adapun pengertian dari nilai dan norma menurut Hasan Mustafa (1992:163) adalah nilai adalah prinsip-prinsip etika yang dipegang kuat oleh individu atau kelompok sehingga mengikatnya dan sangat berpengaruh pada perilaku yang harus dipatuhi oleh setiap anggota suatu unit sosial sehingga ada sangsi negatif dan positif.

Peranan sosialisasi dalam masyarakat pada umumnya tampak jelas, khususnya dalam masyarakat yang tengah atau telah cukup lama berdiri untuk menegakkan berdirinya tradisi-tradisi kemasyarakatan yang kuat, yang menetapkan struktur dan penerapan-penerapan masyarakat. Sosialisasi merupakan bagian yang sangat penting dari kegiatan mempelajari peranan kemasyarakatan. Proses sosialisasi dengan sendirinya telah memberikan pelajaran terhadap kelompok masyarakat mengenai system interaksi antara kelompok-kelompoknya.

\section{Sumber Daya Manusia dalam penyaluran Bantuan Langsung Tunai}

Edward III dalam Widodo (2010:98) mengemukakan bahwa faktor sumberdaya mempunyai peranan penting dalam implementasi kebijakan. Menurut Edward III dalam Widodo (2010:98) bahwa sumberdaya tersebut meliputi sumberdaya manusia, sumberdaya anggaran, dan sumberdaya peralatan dan sumberdaya kewenangan. Sumberdaya Manusia merupakan salah satu variabel yang mempengaruhi keberhasilan pelaksanaan kebijakan. Edward III dalam Widodo (2010:98) menyatakan bahwa:" probably the most essential resources in implementing policy is staff". Edward III dalam Widodo (2010:98) menambahkan " no matter how clear and consistent implementation order are and no matter accurately they are transmitted, if personnel responsible for carrying out policies lack the resources to do an effective job, implementing will not effective"

Sumberdaya Anggaran Edward III dalam Widodo (2010:100) menyatakan dalam kesimpulan studinya "budgetary limitation, and citizen opposition limit the acquisition of adequate facilities. This is turn limit the quality of service that implementor can be provide to public". Menurut Edward III, terbatasnya anggaran yang tersedia menyebabkan kualitas pelayanan yang seharusnya diberikan kepada masyarakat juga terbatas. Edward III dalam Widodo (2010:100) menyatakan bahwa "new towns studies suggest that the limited supply of federal incentives was a major contributor to the failure of the program". Menurut Edward III, terbatasnya insentif yang diberikan kepada implementor merupakan penyebab utama gagalnya pelaksanaan program. Edward III dalam Widodo (2010:101) menyimpulkan bahwa terbatasnya sumber daya anggaran akan mempengaruhi keberhasilan pelaksanaan kebijakan. Disamping program tidak bisa dilaksanakan dengan optimal, keterbatasan anggaran menyebabkan disposisi para pelaku kebijakan rendah.

Sumberdaya Peralatan Edward III dalam Widodo (2010:102) menyatakan bahwa sumberdaya peralatan merupakan sarana yang digunakan untuk operasionalisasi implementasi suatu kebijakan yang meliputi gedung, tanah, dan sarana yang semuanya akan memudahkan dalam memberikan pelayanan dalam implementasi kebijakan. Edward III dalam Widodo (2010:102) menyatakan:

Physical facilities may also be critical resources in implementation. An implementor may have sufficient staff, may understand what he supposed to do, may have authority to exercise his task, but without the necessary building, equipment, supplies and even green space implementation will not succeed.

Sumberdaya Kewenangan Sumberdaya lain yang cukup penting dalam menentukan keberhasilan suatu implementasi kebijakan adalah kewenangan. Menurut Edward III dalam Widodo (2010:103) menyatakan bahwa: Kewenangan (authority) yang cukup untuk membuat keputusan sendiri yang dimiliki oleh suatu lembaga akan mempengaruhi lembaga itu dalam melaksanakan suatu kebijakan. Kewenangan ini menjadi penting ketika mereka dihadapkan suatu masalah dan mengharuskan untuk segera diselesaikan dengan suatu keputusan. Oleh karena itu, Edward III dalam Widodo (2010:103), menyatakan bahwa pelaku utama kebijakan harus diberi wewenang yang cukup untuk membuat keputusan sendiri untuk melaksanakan. 
Sumber daya manusia atau biasa disingkat menjadi SDM adalah potensiyang terkandung dalam diri manusia untuk mewujudkan perannya sebagaimakhluk sosial yang adaptif dan transformatif yang mampu mengelola dirinyasendiri serta seluruh potensi yang terkandung di alam menuju tercapainyakesejahteraan kehidupan dalam tatanan yang seimbang dan berkelanjutan.Dalam pengertian sehari-hari, SDM lebih dimengerti sebagai bagian integral dari sistem yang membentuk suatu organisasi. Oleh karena itu, dalam kajian bidangpsikologi, para praktisi SDM harus mengambil penjurusan industri danorganisasi.

Sebagai ilmu, SDM dipelajari dalam manajemen sumber daya manusiaatau yang biasa disingkat MSDM. Dalam bidang ilmu ini, terjadi sintesa antarailmu manajemen dan psikologi. Mengingat struktur SDM dalam industri atauorganisasi dipelajari oleh ilmu manajemen, sementara manusianya sebagaisubyek pelaku adalah bidang kajian ilmu psikologi.Dewasa ini, perkembangan terbaru memandang SDM bukan sebagaisumber daya belaka, melainkan lebih berupa modal atau aset bagi institusi atauorganisasi. Karena itu kemudian muncullah istilah baru di luar H.R. (humanresources). Disini SDM dilihat bukan sekedarsebagai aset utama, tetapi aset yang bernilai dan dapat dilipatgandakan, dikembangkan dan juga bukan sebaliknya sebagai liability (beban, cost).

Sumber daya manusia memiliki peranan yang sangat penting dalam mewujudkan organisasi yang ideal dan memenuhi standar mutu yang diinginkan oleh masyarakat. Untuk mencapai standar mutu tersebut, maka harus diciptakan situasi yang mendukung. Perhatian dan pengkajian terhadap sumber daya manusia haruslah terus berkembang dan berubah, seirama dengan dinamika kehidupan manusia.

Sumber Daya ManusiaNawawi (2001:43) mengemukakan bahwa terdapat tiga pengertian sumber daya manusia, yaitu: 1) Sumber daya manusia adalah manusia yang bekerja di lingkungan suatu organisasi (disebut juga personil, tenaga kerja, pekerja atau pegawai).2) Sumber daya manusia adalah potensi manusiawi sebagai penggerak organisasi dalam mewujudkan eksistensinya. 3) Sumber daya manusia adalah potensi yang merupakan asset dan berfungsi sebagai modal (non material/non finansial) di dalam organisasi yang dapat mewujudkan menjadi potensi nyata (real) secara fisik dan non fisik dalam mewujudkan eksistensi organisasi.
Pendapat Hasibuan (2014:10) Manajemen sumber daya manusia adalah ilmu dan seni mengatur hubungan dan peranan tenaga kerja agar efektif dan efisien membantu terwujudnya tujuan perusahaan, karyawan, dan masyarakat. Moses N Kiggundu(dalam Indah Puji Hartatik, (2014:14) menyatakan bahwa MSDM adalah pengembangan dan pemanfaatan pegawai dalam rangka tercapainya tujuan dan sasaran individu, organisasi, masyarakat, bangsa,dan internasional yang efektif. Sedangkan menurut kinggudu tersebut tampak jelas memberikan penekanan pada kata "development and utilization of personnel for the effective achievement". Secara garis besar, kalimat tersebut memiliki pemahaman tentang upaya mengembangkan potensi para pegawai melalui beberapa pelatihan, baik yang bersifat umum maupun khusus guna memuncul kan pegawai yang benar-benar berkompetensi dalam bidangnya.

Manajemen sumber daya manusia Schuler, dowling, smart end Huber (Dalam Tjutju Yuniarsih,( 2008:2). Menyatakan bahwa human resourcesmanajemen (HRM) Is the recognition of the importance of an organization's workforce as fital human recourse contributing to the goals of the organization and the utilization of several function and activities to ensure that they are used effectively and fairly for the benefit of the individual the organization and society. (manajeman sumber daya manusia memberikan pengakuan tentang pentingnya tenaga kerja organisasi sebagai sumber daya manusia utama yang memberi kontribusi bagi pencapaian tujuantujuan organisasi serta memberikan kepastian bahwa pelaksanaan fungsi dan kegiatan organisasi dilaksanakan secara efektif dan adil bagi kepentingan individu, organisasi dan, masyarakat. Karena pentingnya peran sumber daya manusia dalam pelaksanaan dan pencapaian tujuan organisasi maka pengelolahan sumber daya manusia harus memperhatikan beberapa aspek penting. Aspek sttafing, pelatihan dan pengembangan motivasi dan pemiliharaan yang secara lebih mendetail.

Sedangkan pengertian manajemen sumber daya manusia menurut Sedarmayanti (2009:6) Manajemen sumber daya manusia adalah seni untuk merencanakan, mengorganisasikan, mengarahkan, mengawasikegiatan sumber daya manusia atau pegawai, dalam rangka mencapai tujuan organisasi.

Pengertian Sumber Daya Manusia secara umum merupakan daya yang bersumber dari 
manusia. Daya yang bersumber dari manusia dapat juga disebut tenaga atau kekuatan (energi atau power). Pada hakikatnya, SDM berupa manusia yang dipekerjakan di sebuah organisasi sebagai penggerak untuk mencapai tujuan organisasi itu. Adapun pengertian sumber daya manusia menurut Sedarmayanti (2009:27) adalah "tenaga kerja atau pegawai di dalam suatu organisasi yang mempunyai peran penting dalam mencapai keberhasilan".

Menurut Bintoro (1997:71) aparatur dimaksudkan untuk mengorganisir secara teratur suatu pekerjaan yang harus dilakukan oleh banyak orang. Aparat adalah tipe dari suatu organisasi yang dimaksudkan untuk mencapai tugas-tugas administratif yang besar dengan cara mengordinasikan secara sitematis (teratur) pekerjaan dari banyak orang.

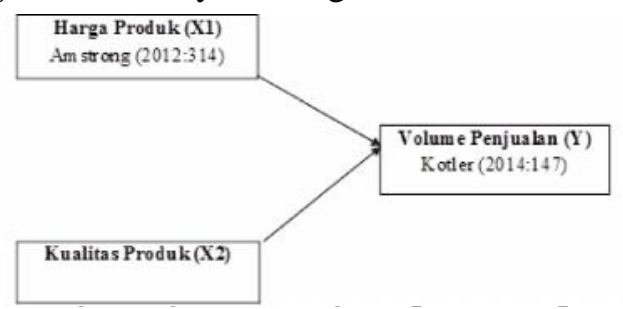

negara akan sangat menentukan kualitas negara sebagai badan hukum publik dalam memberikan pelayanan dan pengayoman kepada masyarakat. Oleh karena itu sangat diperlukan suatu upaya untuk meningkatkan kualitas perilaku aparatur agar mempunyai kemampuan mengayomi dan melayani masyarakatnya, sehingga dapat diharapkan menumbuhkan prakarsa dan peran aktif masyarakat dalam kehidupan berbangsa dan bermasyarakat.

Sumber daya yang paling penting bagi suatu organisasi adalah orang yang memberikan kerja, bakat, kreativitas, dan semangat kepada organisasi". Oleh karena itu kesulitan sumberdaya manusia merupakan sumber masalah dalam organisasi. Konsekuensi dari hai ini adalah tersedianya sumber daya manusia yang mempunyai kapasitas sebagai perencana dan pelaksana program kegiatan. Kapasitas ini ditentukan oleh kapabilitas, kompetensi dan produktivitas kerja.

Widodo (2015:2) menjelaskan "Sumber daya manusia adalah suatu proses yang mencakup evaluasi terhadap kebutuhan SDM, mendapatkan orang-orang untuk memenuhi kebutuhan itu, dan mengoptimasikan pendayagunaan sumber daya yang penting tersebut dengan cara memberikan insentif dan penugasan yang tepat, agar sesuai dengan kebutuhan dan tujuan organisasi di mana SDM itu berada".

\section{METODE}

Penelitian ini jenisnya penelitian deskriptif, yakni penelitian yang dimaksudkan untuk membuat gambaran atau mengambarkan keadaan ataupun kejadian. Penelitian deskriptif menurut Nawawi (1993:63) adalah dapat diartikan"Sebagai prosedur pemecahan masalah yang diselidiki denganmenggambarkan/melukiskan keadaan subyek/obyek penelitian (seseorang, lembaga, masyarakat dan lain-lain) pada saat sekarang berdasarkan fakta-fakta yang tampak atau sebagaimana adanya". Terutama yang berkenaan dengan "penyaluran bantuan langsung tunai di Nanga Ambalau Kecamatan Ambalau Kabupaten Sintang".

Menurut Nasir (1988:211) “pengumpulan data adalah prosedur yang sistematik dan standar untuk memperoleh data yang diperlukan". Dengan demikian penelitian harus menggunakan teknikteknik tertentu dalam pengumpulan data, oleh karena itu dalam penelitian ini digunakan tehniktehnik sebagai berikut:Pengamatan/Observas $i$ : yaitu mengadakan pengamatan secara langsung pada objek-objek dan mencatat hal-hal yang berkaitan dengan masalah yang diteliti.Wawancara atau interview adalah wawancara subjek penelitian yang berhubungan dengan permasalahan yang menjadi objek penelitian. Studi Dokumentasi, yaitu mempelajari dan menggali data sekunder yang diperlukan dalam menunjang penelitian ini seperti tentang gambaran penyaluran bantuan langsung tunai di Desa Nanga Ambalau Kecamatan Ambalau Kabupaten Sintang, disamping itu juga studi dokumentasi dilakukan untuk mandapatkan berbagai macan dokumen berupa buku-buku, laporan teknis yang berkaitan dengan penelitian.

\section{HASIL DAN PEMBAHASAN}

Sosialisasi program bantuan langsung tunai merupakan bagian yang sangat penting dari kegiatan mempelajari peranan kemasyarakatan. Proses sosialisasi dengan sendirinya telah memberikan pelajaran terhadap kelompok masyarakat mengenai sistem interaksi antara kelompoknya. Sosialisasi penting dilaksanakan untuk mengetahui apa tujuan dan manfaat dari program bantuan langsung tunai yang dilaksanakan di Desa Nanga Ambalau. Sosialisasi diperlukan karena akan dikomunikasikan kepada masyarakat apa yang menjadi tujuan dan manfaat dari program bantuan langsung tunai yang dilaksanakan, 
Sosialisasi programbantuan langsung tunai sangat penting dalam mendukung pelaksanaan program yang dilaksanakan. Hal ini dikarenakan sosialisasi sebagai media yang dapat memberikan pemahamanan secara jelas tentang program seperti bantuan langsung tunai bagi masyarakat yang berhak mendapatkannya. Oleh karena itu, dalam implementasi kebijakan sosialisasi menjadi modal dan faktor pendukung dalam pelaksanaan kebijakan.

Sosialisasi merupakan peran utama dalam keberhasilan proses sosialisasi untuk menyebarkan atau menanamkan nilai-nilai dan norma-norma yang terletak dalam materi sosialisasi. Keberhasilan terdapat ditentukan oleh mekanisme yang terencana dan digambarkan dalam pola proses sosialisasi yang baik. Bantuan langsung tunai dijelaskan bahwa progam ini sangat membantu dan bermanfaat bagi masyarakat, maksud dan tujuan pelaksanaan BLT-DD adalah dalam rangka membantu masyarakat miskin terdampak pandemi Covid-19 terhadap sendi-sendi ekonomi dan kesehatan warga masyarakat.

Pemerintah kian sigap dalam membantu meringankan beban masyarakat, khususnya bagi mereka yang terdampak virus corona (covid-19). Pemerintah akan memberikan jenis bantuan bantuan langsung tunai (BLT). Tujuan dari rencana pemberian program bantuan ini adalah guna menjaga daya beli masyarakat di masa corona. Nantinya, semua bantuan tersebut akan didistribusikan ke seluruh masyarakat penerima bantuan langsung tunai, dan menyasar kepada warga terdampak secara langsung maupun tak langsung. Bantuan langsung tunai sebesar Rp 600.000 (Enam Ratus Ribu Rupiah) setiap bulannnya selama tiga bulan. Sehingga, total bantuan yang diterima per keluarga adalah Rp. 1.800.000 (Satu Juta Delapan Ratus Ribu Rupiah). Pemerintah menetapkan sejumlah syarat bagi masyarakat yang ingin mendapatkan bantuan langsung tunai tersebut. Rincian pentingnya adalah pastikan tidak terdaftar di program bantuan sosial pemerintah yang lain, Cek apakah nama penerima sudah terdaftar ke penerima bantuan sosial tunai ke RT/RW Desa setempat, Jika belum, daftarkan diri dengan melampirkan fotokopi KTP untuk diberikan ke kepala desa untuk data penerima diserahkan kepada bank-bank milik negara yang dilibatkan pada program, Tunggu informasi selanjutnya mengenai pencairan dana ke rekening (jika memilih sistem transfer).

Bantuan Langsung tunai ini dilakukan untuk tetap menjaga daya beli masyarakat yang tidak mampu saat pandemi wabah virus corona (Covid-19). Penerima Bantuan Langsung Tunai (BLT) ini didasarkan dari Data Terpadu Kesejahteraan Sosial (DTKS) dan non DTKS. Isi pada saat sosialisasi program bantuan langsung tunai pada masyarakat berkaitan dengan kriteria calon penerima BLT-Dana Desa adalah tidak mendapat bantuan PKH/BPNT/ pemilik kartu prakerja; mengalami kehilangan mata pencaharian (tidak memiliki cadangan ekonomi yang cukup untuk bertahan hidup selama tiga bulan ke depan); mempunyai anggota keluarga yang rentan sakit menahun/kronis.

Pada saat sosialisasi program bantuan langsung tunai disampaikan kepada masyarakat bagaimana mekanisme dan Alur Pendataan Calon Penerima BLT-Dana Desa. Berikut adalah mekanisme pendataan keluarga miskin dan rentan calon penerima BLT-Dana Desa serta penetapan hasil pendataannya: Proses Pendataan, Perangkat Desa menyiapkan data desa yang mencakup profil penduduk desa berdasarkan usia, kesejahteraan, pendidikan, kesehatan, dan disabilitas. Kepala Desa membentuk dan memberikan surat tugas kepada Relawan Desa dan/atau Gugus Tugas COVID-19 untuk melakukan pendataan keluarga miskin calon penerima BLT-Dana Desa. Melakukan pendataan di tingkat Rukun Tetangga (RT) atau Rukun Warga (RW) dengan menggunakan formulir pendataan pada Lampiran 2, atau di tingkat dusun dengan menggunakan aplikasi Desa Melawan COVID-19. Seluruh kegiatan pendataan harus memperhatikan protokol kesehatan.

Penetapan hasil pendataan adalah Kepala Desa memfasilitasi BPD untuk melaksanakan musyawarah desa khusus dengan mengundang perwakilan masyarakat dan pihak lain yang terkait untuk membantu verifikasi dan validasi data terkait penentuan calon penerima BLT-Dana Desa. Berdasarkan hasil musyawarah tersebut, Kepala Desa dan BPD menandatangani daftar keluarga miskin calon penerima BLT-Dana Desa. Merujuk kepada daftar tersebut, desa menyalurkan BLTDana Desa bulan pertama. Kepala Desa menyebarluaskan daftar calon penerima BLT-Dana Desa yang sudah disahkan kepada masyarakat baik melalui papan informasi di setiap dusun dan/atau di tempat-tempat yang strategis dan mudah dijangkau. Desa juga dapat memanfaatkan Sistem Informasi Desa sebagai media informasi publik. Jika ada keluhan dari masyarakat terhadap daftar calon penerima BLT-Dana Desa, maka desa bersama BPD memfasilitasi musyawarah desa untuk membahas keluhan tersebut dan menyepakati solusinya.Daftar calon penerima BLT-Dana Desa dilaporkan dan disahkan oleh Bupati/Wali Kota, 
atau dapat diwakilkan ke Camat. Untuk penyaluran bulan ke dua, desa harus memastikan bahwa data penerima BLT-Dana Desa harus sudah disahkan.

Berdasarkan uraian diatas, maka dengan adanya sosialisasi dalam implementasi kebijakan bantuan langsung tunai, masyarakat mudah untuk memahami mengurusi bantuan langsung tunai, oleh karena itu semuanya diharapkan dapat berjalan dengan baik jika ada kerjasama semua pihak guna melaksanakan sosialisasi program bantuan langsung tunai.

Penyaluran bantuan langsung tunai dana Desa Nanga Ambalau Kecamatan Ambalau Kabupaten Sintang perlu didukung oleh sumber daya manusia aparatur dalam menunjang pelaksanaan penyaluran BLT. Sumber daya manusia di dalam suatu organisasi merupakan hal yang penting. Kompetensi sumberdaya manusia yang memadai. Berkaitan dengan sumber daya manusia bahwa melaksanakan program bantuan langsung tunai tentunya melibatkan semua pihak seperti Pemerintahan Desa dan perangkatnya. Dalam struktur pembentukan relawan gugus tugas Covid-19 tersebut, Kepala Desa menjadi Ketua dan wakilnya adalah Ketua BPD serta anggotanya terdiri dari seluruh perangkat desa, anggota BPD,Linmas, PKK, Karang Taruna dan Lembaga Desa.Sumber daya yang paling penting bagi suatu organisasi adalah orang yang memberikan kerja, bakat, kreativitas, dan semangat kepada organisasi".

\section{KESIMPULAN DAN SARAN}

Penyaluran bantuan langsung tunai dana desa Nanga Ambalau Kecamatan Ambalau Kabupaten Sintang telah dilaksanakan. Pada saat sosialisasi program bantuan langsung tunai disampaikan kepada masyarakat bagaimana mekanisme dan Alur Pendataan Calon Penerima BLT-Dana Desa. Berikut adalah mekanisme pendataan keluarga miskin dan rentan calon penerima BLT-Dana Desa serta penetapan hasil pendataannya: Proses Pendataan, Perangkat Desa menyiapkan data desa yang mencakup profil penduduk desa berdasarkan usia, kesejahteraan, pendidikan, kesehatan, dan disabilitas. Kepala Desa membentuk dan memberikan surat tugas kepada Relawan Desa dan/atau Gugus Tugas COVID-19 untuk melakukan pendataan keluarga miskin calon penerima BLT-Dana Desa.Data yang diterima masyarakat Desa Nanga Ambalau KecamatanAmbalauKabupaten Sintang bantuan langsung tunai Dana Desa Covid 19 sebagai berikut:Rp. 600.000/Bulan masyarakat yang menerima sebanyak 58 Kepala Keluarga untuk bulan April, Mei, Juni Tahun 2020. Sedangkan masyarakat yang menerima untuk bulan Juli, Agustus, September Tahun 2020 sebesar Rp. 300.000/Bulan sebanyak 58 Kepala (KK).
Sumber daya manusia dalam menunjang pelaksanaan penyaluran Bantuan Langsung Tunai Desa Nanga Ambalau melibatkan semua pihak seperti pemerintahan Desa dan perangkatnya. Dalam struktur pembentukan relawan gugus tugas Covid-19 tersebut, Kepala Desa menjadi Ketua dan wakilnya adalah Ketua BPD serta anggotanya terdiri dari seluruh perangkat desa, anggota BPD,Linmas, PKK, dan Lembaga Desa. Berdasarkan kesimpulan diatas maka saran yang dapat penulis ajukan adalah sebagai berikut: Sosialisasi penyaluran bantuan langsung Tunai (BLT) dana desa sebaiknya ditingkatkan dan dipertahankan mengacu pada aturan yang berlaku. Sumber Daya manusia yang ikut dalam penyaluran bantuan langsung tunai Dana Desa sebaiknya diberikan tambahan insentif.

\section{DAFTAR PUSTAKA}

Arikunto. 2000. Prosedur Suatu Penelitian Pendekatan Praktek, Edisi Revisi VI. Jakarta: Rineka Cipta.

Budi Winarno, 2002. Kebijakan Publik Teori dan Proses Edisi Revisi, Media Presindo. Yogyakarta. Handoko, T. Hani 2003.Manajemen. Edisi Kedua. Cetakan Kedelapan belas. Yogyakarta: BPFEYogyakarta.

Hasibuan, Malayu S.P. 2007.Manajemen: Dasar, Pengertian, dan Masalah. Edisi Revisi. Cetakan Keenam. Jakarta: Bumi Aksara.

Handayaningrat. 1989. Manajemen Konflik. PT. Gramedia Pustaka Utama. Jakarta

Mangkunegara, Anwar Prabu, 2001. Manajemen Sumber Daya Perusahaan. PT. Remaja Rosdakarya. Bandung

Nawawi 2001,Sumber Daya Manusia, Reformasi Birokrasi dan Manajemen PegawaiNegeri Sipil, PT. Bandung: Refika Aditama.

Nawawi, Hadari. H. 2007. Metode Penelitian Bidang Sosial. Pontianak: Gadjah Mada University Press.

Kaswan. 2012. Manajemen Sumber Daya Manusia untuk Keunggulan Bersaing Organisasi. Graha Ilmu, Yogyakarta

Sugiyono. 2008." M etode Penelitian Bisnis" . Bandung: Alfabeta

Yuniarsih,Tjutju. 2008. Manajemen Sumber Daya Manusia. Bandung: Alfabeta.

\section{Peraturan Perundang-undangan:}

Peraturan Menteri Dalam Negeri Nomor 20 Tahun 2018 tentang Pengelolaan Keuangan Desa Undang-Undang Nomor 1 Tahun 2020 (Perppu 1/ 2020) tentang Kebijakan Keuangan Negara dan Stabilitas Sistem Keuangan untuk Penanganan Pandemi Corona Virus Disease 2019 (Covid-19) dan/atau dalam Rangka Menghadapi Ancaman yang Membahayakan Perekonomian Nasional dan/atau Stabilitas Sistem Keuangan. 